\title{
South-South relations and the English School of International Relations: Chinese and Brazilian ideas and involvement in Sub-Saharan Africa
}

Relações Sul-Sul e a Escola Inglesa de Relações Internacionais: ideias e envolvimentos chineses e brasileiros na África Subsaariana

http://dx.doi.org/10.1590/0034-7329201400209

JOSEPH MARQUES*

ANTHONY SPANAKOS**

Rev. Bras. Polit. Int. 57 (special edition): 138-156 [2014]

Since at least the beginning of the Great Recession there has been considerable scholarly attention given to South-South relations. Although the deepening relations between developing countries is, in many ways, a continuation of earlier moments, discussions, and projects (such as the Non-Aligned Movement), the rise of China, the resurgence of Russia, and the emergence of Brazil and India, and to a lesser extent Turkey, Indonesia, and other countries - many of which may be considered middle powers (Gilley and O'Neil forthcoming) - have led to much greater visibility for South-South relations (Alexandroff and Cooper 2010).

South-South relations have often been framed by academics and policymakers in traditional realist terms which assume a zero-sum world and the centrality of the US, the actor with the greatest material capabilities. These premises suggest that better relations between China and Brazil (or India, Egypt, or Angola) mean less US influence in that country, region, and the world. Not only must the rise of China (or Brazil and others) signal a decline in US power but so do the deepening itself of South-South relations. ${ }^{1}$ The present essay suggests that this interpretation neither explains South-South relations nor the intentions of foreign policy actors in the global South. Focusing on the foreign policy formulation of China and Brazil— two important "new" actors in global governance and in African

\footnotetext{
* Graduate Institute of International and Development Studies, Geneva, Switzerland (joseph.marques@graduateinstitute.ch).

** Montclair State University, New Jersey, United States (spanakos@gmail.com).

1 An important exception is Dale C. Copeland, "Economic Interdependence and War: A Theory of Trade Expectations," International Security, Vol. 20, no.4 (Spring 1996).
} 
politics - the paper argues that the English School of Realism is better suited to explain the motivation and actions of Southern countries. This will be shown through an analysis of the central ideas of Chinese and Brazilian foreign policy and by analyzing Chinese and Brazilian foreign assistance policy in Sub-Saharan Africa, a region of significant political and economic interest and investment for two leaders of the global South.

\section{Emerging powers}

Zhu Zhiqun confidently writes "China is not a rising power anymore; it has risen." Similarly, the Brazilian Ministry of External Relations (Itamaraty) explains that, since 2003, "foreign policy... [has been] oriented by the concept that Brazil ought to assume a growing role in the international scene..."3 Both countries have pursued greater visibility in global governance and increased commercial and political relations, including with less traditional countries, in recent years. While the moniker of BRICs was originally applied to these two continental-size countries with rapidly swelling middle class consumers and growing domestic markets (along with Russia and India), it has increasingly been used in discussions of "shifts in global power dynamics," especially in journalistic and popular accounts (see Armijo 2007; Spanakos 2012). The BRICS (with the addition of South Africa) as a group may not yet contribute to global governance in formal and direct ways (Spanakos and Marques forthcoming), but the attention it has received is a signal that the world increasingly recognizes its relevance. Similarly, following the Pittsburgh meeting in 2009, the G-20 (which includes both Brazil and China as well as a number of other large developing countries) established itself, in contradistinction from the G-7 (or G-8), as the principal forum for reforms and future proposals on global governance, ranging from financial to environmental matters. Even scholars who insist that the world is unipolar (see Ikenberry et al. 2009) find it necessary to address the "rise of the rest" and the issue (which they dispute) of a diminished role for the US in global affairs.

Recently, China and Brazil have actively pursued better and deeper commercial and political relations with other countries, particularly nontraditional partners (see Brautigham 2009; Almeida 2009). Emphasis has been given to framing these efforts in terms of South-South relations meaning relations among fellow developing countries. Implicit within such discourse is that the US, former colonial powers, and other developed countries conduct diplomacy with developing countries on uneven grounds through non-"democratic" processes. Diplomatic speeches which announce Sino or Brazilian cooperation with African

2 Zhiqun Zhu, "Introduction: Chinese Foreign Policy: External and Internal Factors", China: An International Journal. 9, no. 2 (2011). 185-194. p. 185.

3 Itamaraty, "Resumo Executivo" Balanço de Politica Externa 2003/2010. http://www.itamaraty.gov.br/temas/ balanco-de-politica-externa-2003-2010/resumo-executivo/view. 
governments refer not only to historic ties but to similarity of struggles, friendship and equality. They do so within discourses which advocate a more "multi-polar" and "democratic" world. For traditional realists there is a direct link between the increasing material capabilities of China and Brazil, their increased trade with new partners, and the linkage between increasing South-South cooperation and the drive towards a more multi-polar world.

Perhaps the most common way of understanding the new positions of rising global and regional powers is "power transition theory" which argues that rising and declining powers are likely to enter into conflict—particularly systemic conflict-especially when they have distinct political regimes (Organski and Kugler 1981, Zhu 2005). Whereas the rise of the US was not especially threatening to a declining United Kingdom, a rising China is potentially a different story. Li adopts this framework by arguing that Chinese foreign policy behavior will be peaceful when leaders of the People's Republic of China (PRC) are assured that they will not be cut off from needed markets and resources and suggests that Sino-US conflict is not inevitable. ${ }^{4}$

There are no "Brazil threat" arguments in the US, but there is concern among many that Brazil, which shares many values and interests of the US, often diverges and inevitably demonstrates its growing regional influence by disagreeing with the US or trying to isolate it from regional governance issues. The potential security threat is limited, but the challenge to US influence is taken seriously. The increase of Sino-Latin American trade, the sense of a decline in US influence in the region, and the rise of anti-imperialist presidents (Santibañes 2009; Burbach et al. 2013) have contributed to a sense that not only is the US losing influence "in its own backyard" but that Brazil is partially filling the void. Some have even written of an "end to the Monroe Doctrine." (Khanna 2008, 121).

Although the assumptions made about the rise of China and Brazil are reasonable, it is worth highlighting that the reasonableness of the arguments is, at least partially, the result of epistemic and ontological orientations. Questions about rising powers are often addressed in terms of: how will the central power perceive this rise, not how other actors perceive the rise; whether the rise will affect the system's polarity not how it affects the composition and how rising powers may try to win over third parties in a struggle for global positioning rather than how relations with third parties may be part of internally driven process of stabilizing and deepening economic and political "success." Similarly, South-South cooperation is seen as excluding Northern actors as a way of undermining the power of the North, not as means of communication and sharing which will further cement local development or that will contribute to shifting norms (which are not necessarily oriented toward conflict and relative influence).

4 Zhiqun Zhu, "Power Transition and US-China Relations: Is War Inevitable?", Journal of International and Area Studies, 12, no. 1 (2005) 1-24, and Mastanduno (1999) op. cit.151. 


\section{The English School}

While Chinese intellectuals and foreign policy-makers are well aware that China is no longer geopolitically the "Middle Kingdom," they are also aware that giving such centrality to the US has undesirable political consequences. There is a realist awareness of the US as most capable power but also a reluctance to recognize it as a unipole with universal centripetal energies. Similarly, Brazilian foreign policy-makers have emphasized a state-centric vision of diplomacy, which is always aware of the prominence of the US but which prefers to operate within an international society-informed world (as opposed to one based on poles or capabilities, Vigevani and Cepaluni 2009, Altemani 2010). Indeed, Brazilian foreign policy-makers have often explicitly referred to their worldview as "Grotian," a reference to the English School of Realism (Lafer 2000). While Chinese foreign international relations experts have given considerable effort to establish a "Chinese school of International Relations," many of the principal themes discussed fit well within the English School approach, particularly the emphasis on international society-building (Qin 2005, Lynch 2007).

International society is a core concept for the English School of International Relations. ${ }^{5}$ Bull used "international society" to explain how, in the absence of an overarching government, order was possible. His "anarchical society" was held together by identifying four primary goals of international order (preservation of the system, state sovereignty, peace, and the maintenance of domestic order) which were accomplished by five basic institutions (balance of power, international law, diplomacy, war, and Great Power management). ${ }^{6}$ These, rather than concerns about power transition, better explain Chinese and Brazilian foreign policy particularly in the context of South-South relations.

There has been a resurgence of interest in the English School in recent years for many reasons, ${ }^{7}$ including the potential overlap with constructivist notions about the development of system-binding norms and consensual rules. ${ }^{8}$ Most central to the current paper, however, is the notion of identifying state behavior without over-privileging the position of the United States. It may appear counter-intuitive that balance of power and great power management give greater agency to great and middle powers vis-à-vis a unipole, but analyzing balance of power suggests that there is a constellation of powers not a single one which orders the system.

Similarly, great power management involves more actors than do theories of unipolarity or power transitions. Although analysis of unipolarity, power

5 Alex J. Bellamy Ed., International Society and its Critics, (London: Oxford University Press, 2005).

6 Bull, Hedley, The Anarchical Society: A Study in World Politics (Great Britain: MacMillan Press, 1977), p. xi,16-19.

7 Bellamy (2005) op. cit., Andrew Hurrell, On Global Order: Power, Values, and the Constitution of International Society (New York: Oxford University Press, 2008.

8 Jacinta O'Hagan, “The Question of Culture," Alex J. Bellamy Ed., International Society and its Critics (London: Oxford University Press, 2005) p. 209-228. 
transitions, and great power management all rely on agent legitimacy, ${ }^{9}$ analysis of great power management better explains the agency of multiple actors and why legitimation is increasingly understood in terms of institutionalization of relations within visible multilateral arenas. Rather than understand legitimacy resting on a state's potential to extend power, the English School is more concerned with the legitimacy conferred by the system to that state, only part of which may be the result of its capabilities. Additionally, English School concerns for the building and shifting of international society give greater space for building norms (which can reduce fears of being cut off from markets) while also explaining behavior that exceeds simple acquisition of resources and access to markets.

\section{Core ideas in Foreign Policy}

Qin writes that the rise of US hegemony led to the development of democratic peace theory, while a rising China's IR contributions tend to be oriented towards its peaceful entry into international society. ${ }^{10}$ "Peaceful entry" was conditioned early on by China threat theories, immediate responses to them, and the constraints placed on IR scholars in China until the 1990s. ${ }^{11}$ Since then, Chinese IR has been moving towards developing more original formulations. Analysis of internal discussion of "peaceful rise" and "harmonious development" and other alternative frameworks considered by Chinese elites give serious insight into Chinese approaches to international relations. ${ }^{12}$ International relations scholars and government officials are increasingly pushing an "authentically Chinese" approach to IR, one that draws on "5000 years of civilization and a peace-loving tradition" as well as concepts such as Tianxia (all-under Heaven), Datong (great harmony), and a Zhongyong (middle course). ${ }^{13}$

Qin favors more systematic theoretical development ${ }^{14}$ and, indeed, there has been considerable historical analysis and resuscitation of Tianxia. Jia Qingguo, for

9 Martha Finnermore, "Legitimacy, Hypocrisy, and the Social Structure of Unipolarity: Why Being a Unipole Isn't All It's Cracked Up to Be," World Politics, 61, no. 1, (2009), pp. 58-85.

10 Qin (2011) op. cit. p. 474. One could also argue that hegemony facilitated US transformation of classical realism into neo-realism and its formulation of hegemonic stability theory and power transition theory.

11 Song identifies these as a focus on policy rather than theorizing, and considerable cues and constraints coming from Party and government officials, and limited scholarly fluency in English and familiarity with contemporary international scholars research. Song Xinning, "Building International Relations Theory with Chinese Characteristics," Journal of Contemporary China, 10, no. 26, (2001), p. 61-74.

12 Bonne S. Glaser, and Evan S. Medeiros, "The Changing Ecology of Foreign Policy-Making in China: The Ascension and Demise of the Theory of 'Peaceful Rise," The China Quarterly, no. 190 (June 2007). p. 291-310; see also Sujian Guo and Shiping Hua Ed., New Dimensions of Chinese Foreign Policy, (Lanham: Lexington Books, 2007). Song (2001) is quite pessimistic, while Qin (2011) is somewhat more optimistic about these prospects.

13 Information Office of the State Council, White Paper on China's National Defense (Beijing: Xinhua, 27 July 1998 and Qin (2011) op. cit. p. 478.

14 Qin Yaqing's "Why is there no Chinese international relations theory?" (2005) http://www.irchina.org/en/ xueren/china/qyq.asp accessed on 28 May 2011 Qin Yaqing (2011) op. cit. 
example, returns to earlier periods of Chinese history to argue that a rising China will not lead to a more unstable system, but instead that a "unipolar system poses the greatest challenges for a rising power." 15 While these critiques still employ the language of Western IR and are aimed at appeasing the theoretical unipole in the US, more imaginative and challenging visions are emerging, enabling "authentically" Chinese visions to revisit traditional topics such as sovereignty in new ways. ${ }^{16}$

Zhao Tingyang argues for relations rather than capabilities to determine systemic leadership, that leaders have a responsibility to those within the system (not just their citizens), and that legitimacy is sustained by the legitimacy conferred upon the leader. ${ }^{17}$

Lynch's survey of Chinese elite writing in neibu (internal circulation) and social science journals shows that Chinese elites and policy-makers display a clear preference for the basic concepts of international society in that their thinking is state-centric, includes important space for norm construction, and is based firmly on the notion of external sovereignty. ${ }^{18} \mathrm{He}$ found that sovereignty and differentiation between states was considered an unchanging "ontological" condition. Sovereignty is a fundamental principle for Chinese foreign policy and when molded by Chinese participation in international society it is consistent with English School visions. ${ }^{19}$

The centrality of states leads not to Hobbesian anarchy but Grotian efforts toward society-building. President Hu's 2005 "Harmonious World" speech highlights the importance of building international society. He explains:

1. multilateralism should be upheld to realize common security...;

2. all nations [should] ...encourage and support efforts to settle international disputes or conflicts through consultations and negotiations;

3. mutually beneficial cooperation should be upheld to achieve common prosperity with developed economies shouldering a greater responsibility for a universal, coordinated and balanced development in the world; [and]

15 See Michael Glosny, "China and the BRICs: A Real (but Limited) Partnership in a Unipolar World." Polity, 42, no. 1, p. 100-129, pp. 104

16 Allen Carlson, "Moving Beyond Sovereignty? A brief consideration of recent changes in China’s approach to international order and the emergence of the tianxia concept," Journal of Contemporary China, 20 no. 68 (January 2011) p. 89-102.

17 Zhao Tingyang, "Rethinking Empire from a Chinese Concept 'All-under-Heaven' (Tian-xia)," Social Identities, 12 no. 1, (January 2006), p. 29-41, pp. 38-39, 39. This reimagining involves both re-claiming theory from 'Western' theories as well as creating the ground for a more sophisticated and less dogmatic position on noninterference and sovereignty (see Carlson 2011 op. cit). The latter is especially important as the rise in China leads to a change in expectations and China is no longer expected to be a systemic critic, nor a responsible stakeholder, but a leader.

18 Daniel C Lynch, "Envisioning China’s Political Future: Elite Responses to Democracy as a Global Constitutive Norm," International Studies Quarterly, 51, no. 3, (2007), p. 701-722.

19 See Carlson (2011) op. cit. 
4. the spirit of inclusiveness must be upheld to build a world where all civilizations coexist harmoniously and accommodate each other. ${ }^{20}$

Hu's commitments to collective institutions within the international system, working within multilateral institutions, engaging in diplomacy, and following international law are entirely consistent with the English School tradition. ${ }^{21}$

During the global recession of 2008, some commentators suggested a G-2 wherein Chinese and US officials would "co-manage" the global system in the tradition of great power management. While the Chinese government rejects "hegemony" and any G-2 as too "exclusive," ${ }^{22}$ it does pursue great power management through international institutions, regional associations, and even bilateral relations. During the Strategic and Economic Dialogue in July 2009 in Washington, D.C., Chinese and US treasury and foreign affairs officials discussed a broad range of bilateral and global issues and pledged to work together towards softening the current global crisis and heading off future crises in the areas of climate change and environmental degradation. China has worked with the US and other countries to play a more active role in talks over North Korea's nuclear ambitions, and has moved away from traditional non-intervention approaches with Sudan and Burma. Additionally, it has pushed for a larger role for the G-20 in global governance and greater representation for developing countries in the World Bank and the IMF. ${ }^{23}$ This behavior shows consistent support for great power management even if China, at times, aims to expand the category of "great power" away from the usual suspects.

Similarly, it is worth reconsidering scholarship about the rise of Brazil as a regional power. ${ }^{24}$ The "importance" of Brazil as a global player has become increasingly "obvious." ${ }^{25}$ When the BRICs (Brazil, Russia, India, and China) were

20 Ding, Shing. “To Build A 'Harmonious World': China's Soft Power wielding in the Global South,” Sujian Guo and Jean-Marc F. Blanchard Ed., "Harmonious World" and China's New Foreign Policy (Lanham: Lexington Books, 2008) p. 105-124, pp. 108-109.

21 This is not to say the PRC regularly follows international law or applies international standards within its borders, only that its compliance with international law has increased in recent years and its rhetorical discussion of such norms suggest that it aims at being a 'responsible stakeholder.' See Gerald Chan, China's Compliance in Global Affairs: Trade, Arms Control, Environmental Protection, Human Rights, (Hackensack: World Scientific, 2006). That the speech was delivered at the $60^{\text {th }}$ anniversary of the United Nations, an international institution of which China was once a fierce critic, is telling.

22 see Elizabeth C. Economy, and Adam Segal, "The G-2 Mirage,” Foreign Affairs, 88, no. 3, (May/June 2009), p. $14-23$.

23 Gregory Chin and Eric Helleiner, "China as a Creditor: A Rising Financial Power?" Journal of International Affairs, 62, no. 1, (Fall 2008), p. 87-102.

24 Andrés Malamud, "A Leader Without Followers? The Growing Divergence Between the Regional and Global Performance of Brazilian Foreign Policy.” Latin American Politics and Society. 55 (3). 2011, p.. 1-24 and Jean Friedman-Rudovsky, "The Bully from Brazil," Foreign Policy, 20 July 2012, http://www.foreignpolicy.com/ articles/2012/07/20/the_bully_from_brazil accessed on 20 july 2012.

25 Leslie Elliott Armijo, Leslie and Sean W. Burges, "Brazil, the Entrepreneurial and Democratic BRIC," Polity, 42, no. 1, (January 2010), p. 14-37. See also Andrés Malamud, "A Leader Without Followers? The Growing Divergence Between the Regional and Global Performance of Brazilian Foreign Policy," Latin American Politics and Society, 55, no. 3, p. 1-24. op. cit. 
first selected as large, growing developing markets with great upside for investors by Goldman Sachs, there was plenty of reason to doubt whether Brazil belonged to that group. ${ }^{26}$ There were also concerns over how much leftist former labor leader Luiz Inácio Lula da Silva moderated his views on capitalism ${ }^{27}$ and that Lula had given the foreign policy portfolio to the radicals in his coalition. ${ }^{28}$

But through statesmanship, the rise of commodity prices, crisis in the developed world, and not being Bolivarian Venezuela, ${ }^{29}$ Brazil emerged from the first decade of the twentieth century as a regional power and an important global actor. In his inaugural speech in 2003, Lula declared "this country has everything to be the equal of any other country in the world. And we will not give up on this goal." 30 Since then, Brazil opened 33 new embassies and 19 new consulates, created the India-Brazil-South Africa (IBSA) group, successfully competed to host the 2014 World Cup and the 2016 Summer Olympics, was critical in rejecting the US plan for a Free Trade Area of the Americas and at the Doha Round of the World Trade Organization, and was an important force behind the increased importance of the G-20.

For all the excitement about Brazil, the general approach of Brazilian diplomats and foreign policy specialists remains largely unchanged $:^{31}$ traditional goals of development, non-intervention, regional peace, and diversification of export markets remain, as do preferences for diplomacy and multilateralism over coercion and uni-/bilateralism. ${ }^{32} \mathrm{New}$ opportunity structures have led to more important discussions about leadership at the regional and global level, but this is done with concern for ideological and historical continuity. ${ }^{33}$ On a global level, Lula has preferred multilateral over unilateral approaches, consensus and negotiation over confrontation." ${ }^{34}$ Rousseff has continued this, while being more conciliatory towards the US. Diversification and the pursuit of multilateralism may reduce

26 The BRICs became BRICS in 2011 when South Africa joined the group. Paulo Leme, "The 'B' in BRICs: Unlocking Brazil's Growth Potential,” BRICs and Beyond, (New York: Goldman Sachs Paper Number 23, 2007), p. $75-84$, pp. 75.

27 Anthony Peter Spanakos and Lucio Renno, "Speak Clearly and Carry a Big Stock of Dollar Reserves: Sovereign Risk, Ideology and the Presidential Elections in Argentina, Brazil, Mexico, and Venezuela," Comparative Political Studies, 42, no. 10, (Oct 2009), p. 1292-1316.

28 Paulo Roberto de Almeida, "Lula's Foreign Policy: Regional and Global Strategies," Joseph L. Love and Werner Baer Ed., Brazil under Lula: Economy, Politics, and Society under the Worker-President (New York: PalgraveMacmillan, 2009), pp. 167-183.

29 Vigevani and Cepaluni (2009) op. cit. and Almeida (2009), op. cit.

30 Andrew Hurrell, "Brazil and the New Global Order." Current History. February 2010. p. 60-66.

31 Almeida (2009) op. cit. and Sean W. Burges, Brazilian Foreign Policy after the Cold War, (Gainesville: The University of Florida Press, 2009).

32 The earlier portion of this paper addressed the issue of the rise of the left, a phenomenon which has been seen across Latin America broadly. The following sections focus on Brazil whose "region," geostrategically and economically speaking, is primarily South America. See Vigevani and Cepaluni (2009) op. cit.

33 Burges (2009) op. cit.

34 William Barr, Brazil Alert: The First Six Months of Lula: An Impressive If Precarious Start. Center for Strategic and International Studies. Vol. XI. Series 25. Washington D.C.: Hemisphere Focus, 2003. 
US policy influence but Brazil does not diversify its markets or act in multilateral fora to balance only against the US. Rather it aims to increase its own autonomy vis-à-vis the US, Europe, and other foreign actors. ${ }^{35}$

The English School is dominant in the content and study of Brazilian foreign policy. ${ }^{36}$ Celso Lafer (Foreign Minister in 1991 and 2001-2002) identifies Brazilian nationalism with "a Grotian vision," the approach generally considered closest to the English School, ${ }^{37}$ which best fits Brazilian interests. He writes, "[g] iven the interplay of variably shaped alliances allowed for in a world of undefined polarities, multilateral fora constitute, for Brazil, the best chessboards for the country to exercise its competence in the defense of national interests." 38 Elsewhere, he argues "that a country's foreign policy identity is forged through an ongoing dialectical relationship with the external." ${ }^{39}$ That breadth of participation is linked to multipolarity by Foreign Minister Celso Amorim (1993-1995 and 2003-2011) who declared that Brazil wanted "to increase, if only by a margin, the degree of multipolarity in the world." 40 A US-centered position sees this as soft balancing against the US, but, as suggested earlier, Brazil does not really "balance" against the US as much as it pursues internal development by advancing its own interests within the international arena more broadly.

Vigevani and Cepaluni identify autonomy of government operations, particularly from the external (not limited to the US), as one of the fundamental elements of long-term Brazilian foreign policy. ${ }^{41}$ Trade diversification-in practical terms, the goal of maintaining roughly proportionate commercial activity with the US, Europe, Asia, and South America—is not simply a defensive move against US use of trade to influence Brazilian policies, but is used as leverage in other external markets in Europe and Asia. ${ }^{42}$ Trade diversification also has a fundamental internal element in terms of reducing risk from external shocks and improving influence in a broad range of countries. All of these elements have proven critical at various moments in Brazilian development.

35 Altemani de Oliveira (2010) op. cit. p. 33.

36 Almeida (2009) op. cit., Vigevani and Cepaluni (2009) op. cit.

37 Although they considered their approach to include elements of all three approaches, the English School over time has been most in-line with a 'Grotian' analysis. See Celso Lafer, "Brazilian International Identity and Foreign Policy: Past, Present, and Future," Daedalus, 129, no. 2, (Spring 2000), p 207-238, pp. 222.

38 Ibid. p. 229.

39 In Burges (2005) op. cit. p. 1137.

40 In Andrew Hurrell, "Hegemony, liberalism and global order: what space for would-be great powers?” International Affairs, 82, no. 1, (2006) p. 1-19, pp. 15.

41 (2009) op. cit. p. 6-7.

42 Altemani de Oliveira (2010), op. cit. p. 44. 


\section{China in Africa}

According to the Five Principles of Peaceful Coexistence, ${ }^{43}$ China respects recipient countries' right to independently select their own path and model of development according to their unique conditions. Accordingly, China neither interferes in recipient countries' internal affairs nor seeks political privileges for itself when providing foreign assistance. In line with the main pillars of Chinese political thought, China is committed to "cooperative and win-win development" since its domestic economic development requires "a peaceful international economic and political environment." ${ }^{44}$ Just as the English School promotes the concept of an "international society," the mainstream of Chinese foreign policy is "to engage peacefully with its neighbors." ${ }^{45}$ These principles have allowed China to position itself as a developing country willing to share its developmental expertise in the spirit of South-South cooperation.

Although China's primary objective in Africa is to secure access to critical sources of energy, it is engaged in aid projects to further economic development, increase people to people exchanges, and contribute to greater support at regional and global institutions. Importantly, the language and structure of Chinese SouthSouth policies reflect efforts to build normative schemes that it sees as alternative to the power-centered zero-sum approaches it identifies with the West.

Chinese extensive engagement with Africa is largely based on the Eight Principles for Economic Aid and Technical Assistance to Other Countries ${ }^{46}$ established by Zhou Enlai in 1964. The Eight Principles are: mutual benefit; no conditions attached; no-interest or low-interest loans should not create a debt burden for the recipient country; to help the recipient nation develop its economy; not to create recipient nation dependence on China; to help the recipient country with projects that need less capital and quick returns; aid in kind must be of high quality and at the world market price; to ensure that the technology can be learned and mastered by the locals; that Chinese experts and technicians working for the aid recipient country are treated equally as the local ones with no extra benefits for them. ${ }^{47}$

China has provided aid to Africa since 1956 and its level of assistance has grown dramatically over the last decade, accounting for nearly half of all China's

43 First announced by Premier Zhou Enlai in 1954 during negotiations with India regarding Tibet. Available at <http://wiki.china.org.cn/wiki/index.php/Five_Principles_of_Peaceful_Coexistence>.

44 See Matt Ferchen, “Time to Rethink China’s Peaceful Development Policy”, November 6, 2013. Carnegie Endowment online http://carnegieendowment.org/2013/11/06/time-to-rethink-china-s-peaceful-developmentpolicy/gsv3?reloadFlag=1 accessed November 19, 2013.

45 See Niu Haibin, page 184 in "Emerging Global Partnership: Brazil and China" in Revista Brasileira de Politica Internacional, no. 53 (special edition), pp. 183-192, 2010.

46 Available at <http://english.gov.cn/official/2011-04/21/content_1849913_10.htm>.

47 See "China's African Aid: Transatlantic Challenges - A Report to the German Marshall Fund of the United States”, April 2008 by Deborah Brautigam, p. 9. 
foreign aid. ${ }^{48}$ China's reputation as a trusted partner derives from its historic support for liberation struggles in Africa as well as its shared colonial experience, developing country status and a common focus on poverty and development with an emphasis on mutual development. Chinese diplomacy has built on this by forging friendships with "non-aligned" nations as a legacy of the Cold War and promoting its "one China" policy with the objective of excluding Taiwan whenever possible and garnering support for joint strategies in international organizations.

\section{Foreign assistance}

China has become a major development partner for many African nations by effectively providing "alternative routes to development." ${ }^{49}$ Like other emerging donors, China has resisted adopting the international aid transparency standards established by the Organization for Economic Cooperation and Development's definition of Official Development Assistance (ODA). ${ }^{50}$ Chinese aid is often preferred by recipient countries given its less stringent terms regarding transparency and monitoring requirements. China has often filled the void by providing financing for projects deemed either too risky on the part of traditional donors or assisting with projects that many African countries find more useful and more appropriate to their immediate needs.

Africa has been the main recipient of Chinese loans and development assistance for infrastructure, natural-resource development programs and public works projects. Chinese aid consists of a mix of traditional development assistance from the central government and foreign investment from Chinese companies. China's "checkbook diplomacy" consists primarily of three types of aid: grants, interest-free loans and concessional loans. The Ministry of Commerce (MOFCOM) is responsible for disbursing grants and zero-interest loans, while the Export-Import Bank of China (Eximbank) is responsible for the concessional loans. ${ }^{51}$

The most popular "model" of Chinese aid to countries rich in natural resources is the "Angola model," whereby the Chinese government mandates a Chinese public company to carry out infrastructure projects chosen by the African government concerned with the support of the EximBank. In return, the African government grants Chinese companies the right to extract natural resources (oil,

48 Figures based on disbursement amounts for 2009 in "China's Foreign Aid" by Information Office of the State Council - The People's Republic of China, April 2011, Beijing.

49 See "The Impact of the Chinese Presence in Africa", An Africapractice report prepared for JETRO London by Isaac Idun-Arkhurst and James Laing, 2007.

50 China, Brazil and India, have, however, committed to greater transparency and accountability by signing on to OECD - DAC's Fourth High Level Forum's final document in 2011 in Busan. See "China, India and Brazil in Africa: Effects on Development Policy” by Sebastian Barnet Fuchs, KAS International Reports, February 1, 2013.

51 Eximbank is one of China's three big "policy banks" together with the China Development Bank and China Agriculture Bank). 
iron ore, etc.) through the acquisition of shares in a national company or by granting it a license. ${ }^{52}$

In the absence of a centralized aid agency, many different actors are involved in shaping and implementing aid programs in China: the State Council, the Ministry of Commerce MOFCOM and the Ministry of Foreign Affairs. Big banks and state-owned companies (SOEs) are also active participants in the international assistance process by using aid money to support their commercial ventures overseas. ${ }^{53}$ The Ministry of Commerce is authorized by the State Council to oversee foreign aid. To better coordinate the growing demand for aid and to organize its public diplomacy regarding Africa, China established the Forum on China-Africa Cooperation (FOCAC) in Beijing in October 2000. FOCAC meets every three years (alternating between China and Africa) and aims to strengthen cooperation ties between China and African states and jointly meet the challenges of economic globalization and promote common development. It has been an important channel for collective consultation, dialogue, and partnership. Pledges of assistance from China to Africa have doubled at each FOCAC summit: in 2006, US\$ 5 billion was pledged; in 2009, US\$ 10 billion; and, in 2012, US\$ 20 billion. ${ }^{54}$

Another diplomatic venue used to foster closer consultation and diplomatic exchange is the Forum for Economic and Trade Cooperation between China and Portuguese-Speaking Countries (commonly known as the Macau Forum) established in $2003 .{ }^{55} \mathrm{~A}$ ministerial conference is held every three years and is largely financed by the central government in Beijing as well as the special administrative region of Macau. Economic and trade relations between all parties (the 8 lusophone countries, namely Angola, Mozambique, Guinea Bissau, Cape Verde, Sao Tome and Principe, East Timor, Portugal, and Brazil, as well as China) are expected to amount to US\$ 160 billion in 2016. The Macau Forum has also established a US\$ 1 billion fund - the Fund for Development Cooperation between China and the Portuguese-speaking Countries.

\section{Companies}

As a result of China's aggressive commercial policy, Africa has also become a "strategic training ground for Chinese companies." China's "Going Global"

52 For a good review of China's oil-backed loans see Alves, Ana Cristina (2013), "Chinese Economic Statecraft: A Comparative Study of China's Oil-backed Loans in Angola and Brazil" in Journal of Current Chinese Affairs, 42, 1, 99-130.

53 See "Charity Begins at Home" by Philippa Brant in Foreign Affairs, 13 Oct. 2013, <http://www.foreignaffairs. com/articles/140152/philippa-brant/charity-begins-at-home>, accessed November 9, 2013.

54 See "The Sino-Africa Relationship: Toward a New Strategic Partnership, by Zhang Chun Available at <http:// www.lse.ac.uk/IDEAS/publications/reports/pdf/SR016/SR-016-Chun.pdf>, accessed November 20, 2013.

55 China has also established similar programs for other regions such as the Caribbean states, Arab states, etc.

56 Jetro, op. cit. pg. 2. 
strategy (promoted by Beijing since the entrance of China into the WTO in 2001), has encouraged Chinese companies to invest abroad, gain valuable experience and "enhance China's global power status." 57 In Africa this has involved primarily investments in oil, gas, infrastructure, telecommunications and most recently, food production.

It is estimated that over 2000 companies, ranging from resource and construction firms to textile manufacturers and telecommunication companies are currently working in Africa. ${ }^{58}$ China's state-owned enterprises (SOEs) seek new markets and new destinations to expand their overseas investments. A recent inducement is the US\$ 5 billion FOCAC fund managed by the China Development Bank (CDB) to help private Chinese companies invest in Africa. The political and historic relations between SOEs and the central government in China serve as a crucial competitive advantage for Chinese companies. Because its investments are backed by state funding, Chinese companies can afford to take more risks than companies from many industrialized countries.

Chinese SOEs are actively involved in China's aid policy by helping recipient countries make aid requests and conduct feasibility assessments of proposed aid projects. Once established in Africa, most Chinese companies are likely to pursue other tenders in the host country given their competitive financial advantage and technical know-how. China has also set up several Special Economic Zones (SEZs) throughout Africa (including Zambia, Mauritius Nigeria, Egypt and Tanzania).

Chinese banks and financial institutions are also beginning to expand their activities in Africa (i.e. Industrial and Commercial Bank of China's acquisition of $20 \%$ of Standard Bank in South Africa). South Africa's Central Bank has recently decided to diversify its foreign reserves by buying Chinese bonds (fellow BRICS countries have made similar announcements).$^{59}$ Discussions also continue between China and South Africa (and other BRICS partners) regarding the use of their own currencies to substitute the US dollar to finance their bilateral trade. Though still a remote reality this helps burnish China's reputation as one of the architects of a new global trading and financial order.

\section{Brazil in Africa}

Brazil and China have very different goals in Africa. Blessed by an abundance of important natural resources and a growing supply of energy, Brazil looks to expand its engagement in Africa beyond the usual resource-seeking motives. Brazil also draws on fundamental foreign policy principles including respect for

57 Jetro, op. cit. p. 10

58 See "Special Report: In Africa, can Brazil be the anti-China? By David Lewis, Reuters, February 23, 2011.

59 See South Africa to invest in China bonds in Financial Times, November 5, 2013 available at <http://www. reuters.com/article/2011/02/23/us-brazil-africa-idUSTRE71M1I420110223>, accessed November 21, 2013. 
sovereignty, non-interference, a preference for multilateral diplomacy and the peaceful resolution of conflict through international law. While Brazil and China have very extensive relations and share considerable interest in shaping global governance, this does not prevent Brazil from presenting itself as an alternative to Chinese-style investment in Sub-Saharan Africa. Brazil seeks to become a credible partner for Africa's development challenges rather than merely a "business" partner.

Brazil regards Africa as a natural extension for its economic interests, diplomatic ambitions, and its innovative program of international assistance. Brazil gained enormous visibility and diplomatic goodwill with President Lula's high profile "presidential diplomacy." 60 Brazil's extensive diplomatic footprint throughout the continent is the result of the country's investment in establishing stronger links with many African countries as well as the continent's main institutions: Southern Africa Customs Union (SACU), the Economic Community of West African States (ECOWAS), Partnership for Africa's Development (NEPAD), the African Union (AU) and the Community of Portuguese Speaking Countries (CPLP).

China's involvement in Africa, especially in Portuguese-speaking countries, poses a direct challenge to Brazilian interests. There are competing interests between Brazil and China in the region and both countries use different strategies in countries like Angola, where Brazil plays the cultural diplomacy "soft power" card drawing on its historic solidarity and China counters by offering attractively priced loans.

Unlike China, Brazilian cooperation is not focused on large infrastructure but rather on human development, institutional capacity-building and the sharing of best practices in the field of education, health and poverty reduction as developed over time by the Brazilian government. Brazil relies heavily on its specialized state agencies including SENAI (technical training), EMBRAPA (agricultural research) and FIOCRUZ (health research). SENAI has established learning centers in Angola, Zambia, Mozambique, Guinea-Bissau, and Cape Verde. ${ }^{61}$ EMBRAPA has opened an office in Ghana and is helping several countries with cotton, rice and ethanol production. FIOCRUZ is helping Mozambique with AIDS medicine production as well as helping many other countries in the fight against malaria and tuberculosis.

Brazil's solidarity with Africa is due, in large part, to its large population of African descent. In addition, Brazil maintains extensive historical and cultural ties with many African countries, especially in West Africa (i.e. Nigeria, Benin, Togo, Ghana, etc.) and lusophone Africa (Angola, Mozambique, Guinea Bissau, Sao Tome and Principe and Cabo Verde).

60 Anecdotal evidence suggests that the recent election of Brazil's candidate to lead the World Trade Organization in Geneva counted with the overwhelming support of African votes in his favor - the result of the enormous diplomatic goodwill garnered over the years from its economic cooperation efforts.

61 See "Brazil-Africa Technical Co-Operation - Structure, Achievements and Challenges" by Ana Cristina Alves, August 7, 2013, South African Institute of International Affairs, Policy Brief 69. 


\section{Alternative views}

At the moment no other country can compete with China's economic largesse in Africa. In 2012, China invested more than US\$ 40 billion in African countries and promised US\$20 billion in aid during the upcoming three years. In 2012, the total trade between China and Africa was US\$ 128 billion. ${ }^{62}$

China's emergence as a major source of international assistance for Africa has aroused both enthusiasm and criticism among other global donors. Public perception of China in Africa is also growing more critical, prompting a review of Africa's current development model as well as China's aid effectiveness. Recent reports concluded that "the short-term benefit China provides to Africa is intrinsically flawed and has long-term negative consequences" 33 and (fails) "to promote democracy, equitable and sustainable development, and environmental preservation." " 44 Several African leaders have spoken out against some of the drawbacks of Chinese aid and regional organizations (i.e. African Union) have begun playing a role by representing recipient nations' development priorities.

China's aggressive search for natural resource suppliers has produced competing views about Chinese aid. The principle of "no conditionality" is often blamed for undermining recipient countries' own efforts to improve governance and macroeconomic reform. The rapid rise of emerging donors such as China, has raised fears that they are "encouraging poor policies, lowering standards and increasing debt burdens in countries to which they are offering aid." ${ }^{65}$ On the other hand, alternative evidence suggests that "as a result of trade links with China, states in Africa have enjoyed higher growth rates, better terms of trade, increased export volumes and higher public revenues." 66

Angola is typical of many African nations, for having adopted the "Chinese" model of development whereby a country must first deal with its economic development, mainly basic infrastructure and macroeconomic stability, prior to any political and social development, Many African countries have criticized Western donors for their frequent neglect of African infrastructure. Immediately following its internal civil war, Angola embarked on an ambitious plan for national reconstruction with discussions with the International Monetary Fund and other

62 Though China's investments in Africa have outpaced the US's since 2009, the US remains a key participant in Africa (US\$ 100 billion in trade). See "Will China Win the Battle Over Africa?" by Raluca Besliu, July 13, 2013 in Foreign Policy Journal, http://www.foreignpolicyjournal.com/2013/07/13/will-china-win-the-battleover-africa/ accessed November 20, 2013.

63 See "Top Five Reasons Why Africa Should Be a Priority for the United States" by Brookings Institution (2013).

64 See "China's Foreign Aid Activities in Africa, Latin America and Southeast Asia”, p.1, Congressional Research Service, February 25, 2009.

65 See "Whose aid? Whose influence? China, emerging donors and the silent revolution in development assistance" by Ngaire Woods in International Affairs 84:6 (2008), 1205 - 1221, page 1205.

66 Ibid. 
international lenders. Western insistence on economic conditionality led to Angola's acceptance of a US\$ 2 billion loan package from China. China's "noninterference" policy is clearly a comparative advantage and served as an effective solution to Angola's problems at the time. From that first loan in 2003 China's economic relations with Angola have evolved to include several additional loans and have reached the level of a China-Angola Strategic Partnership in 2010.

Contemporary Chinese policy in Africa is driven mainly by economic pragmatism. China seeks to acquire oil and strategic metals; do business by expanding the market for Chinese products; and obtain political goodwill by nurturing strategic partnerships. All of this is done under the umbrella of its traditional foreign policy principles. Going forward, China will learn how to better balance its ambitious pursuit of resources and active commercial strategy in order to guarantee the peaceful and stable political and economic environment necessary for its continued domestic development.

\section{Conclusions}

South-South cooperation is an integral aspect of Chinese and Brazilian foreign policy and it is part of a broader strategy of assuming a more prominent role in global affairs through deepening relations and international society. China's international assistance, based on equality and cooperation, reflects China's values and principles including "mutual benefit, reciprocity and common prosperity." 67 Deng Xiaoping's dictum that China needs to maintain a peaceful external environment to focus on development remains a fundamental belief and allows China to evolve and contribute to a more "harmonious world." The Chinese principle of domestic order and the English School's focus on international societybuilding are important strands in China's foreign and South-South policies and confirm the relevance of the English School to Chinese foreign policy analysis.

Brazil's long-term interest in maintaining autonomy, facilitating its own development and working through multilateral institutions reflect a more direct influence of English School approaches. As Brazilian material and ideational capabilities have improved it has sought to make its presence in international society more visible, and, like China, has seen Africa as an area where there is relatively less influence of great powers and where there are shared interests, histories, and needs.

Although Chinese and Brazilian interests and visions (such as human rights) are not perfectly aligned, their foreign policies are best conceived within the epistemological space of English School approaches to International Relations. This does not mean that Chinese and Brazilian diplomats, corporations, and non-governmental organizations do not and will not compete for influence and

67 See China’s African Policy, January 2006 <http://english.peopledaily.com.cn/200601/12/eng20060112_234894. htm>, accessed November 26, 2013. 
resources in Africa. Rather, the suggestion is that the default assumption is that competition, cooperation, and any combination will be envisioned not as inherently zero-sum but as efforts to broaden each agent's participation in a growing and changing sense of international society.

\section{Bibliographic references}

Alexandroff, Alan S. and Andrew Cooper Ed., Rising States, Rising Institutions: Challenges for Global Governance, Washington, D.C.: Brookings Institutions, 2010.

Almeida, Paulo Roberto de. "Lula’s Foreign Policy: Regional and Global Strategies," Joseph L. Love and Werner Baer Ed., Brazil under Lula: Economy, Politics, and Society under the WorkerPresident (New York: Palgrave-Macmillan, 2009), pp. 167-183.

Altemani de Oliveira, Henrique. "Brazil and China: From South-South Cooperation to Competition?” Alex E. Fernández Jilberto and Barbara Hogenboom Ed. Latin America Facing China: South-South Relations Beyond the Washington Consensus. New York: Berghahn Books. p. 33-53. 2010.

Alves, Ana Cristina. 2013a. “Chinese Economic Statecraft: A Comparative Study of China's Oil-backed Loans in Angola and Brazil" in Journal of Current Chinese Affairs, 42, 1, 99-130. . 2013b. "Brazil-Africa Technical Co-Operation - Structure, Achievements and Challenges”, 7 August, South African Institute of International Affairs, Policy Brief 69.

Armijo, Leslie Elliott. “The BRICs Countries (Brazil, Russia, India, and China) As Analytical Category: Mirage or Insight?" Asian Perspective. 2007. 31 (4). Available at: <http://ezproxy. library.nyu.edu:2082/pqdweb?RQT =318\&pmid=114709\&TS=1304697882\& clientId=9269 \&VInst=PROD\&VName=PQD\&VType $=P Q D>$.

Brautigam, Deborah. 2009. The Dragon's Gift: The Real Story of China in Africa. Oxford: Oxford University Press.

Brookings Institution (2013), Top Five Reasons Why Africa Should Be a Priority for the United States, Washington, D.C.

Bull, Hedley. The Anarchical Society: A Study in World Politics. Great Britain: MacMillan Press. 1977.

Burbach, Roger, Michael Fox, and Federico Fuentes, Latin America's Turbulent Transitions: The Future of Twenty-First Century Socialism, London: Zed Books, 2013.

Burges, Sean W. Brazilian Foreign Policy after the Cold War. Gainesville: The University of Florida Press. 2009.

Chan, Steve, "Is There a Power Transition between the US and China?" Asian Survey, XLV (5), Sept/Oct 2005. pp. 687-701.

Economist. "A Special Report on Business and Finance in Brazil: Getting it together at last." Economist. 12 November 2009.

Garcia, Marco Aurélio. “Brazilian Future.” Opendemocracy.net 16 July 2003 <http://www. opendemocracy.net/democracy-think_tank/article_1367.jsp>. 
Gilley, Bruce and Andrew O'Neil Ed., Middle Powers and the Rise of China, Washington, D.C.: Georgetown University Press, forthcoming.

Haibin, Niu (2010). "Emerging Global Partnership: Brazil and China”, Revista Brasileira de Politica Internacional, no. 53 special edition, pp. 183-192.

Idun-Arkhurst, Isaac and James Laing (2007). The Impact of the Chinese Presence in Africa (An Africapractice report prepared for JETRO). London: Africapractice.

Ikenberry, John G., Michael Mastanduno, and William C. Wohlforth, "Introduction: Unipolarity, State Behaviour, and Systemic Consequences.” World Politics, 61 no. 1, (January 2009), p. 1-27.

Lafer, Celso. "Brazilian International Identity and Foreign Policy: Past, Present, and Future," Daedalus, 129, no. 2, (Spring 2000), p 207-238, pp. 222.

Lum, Thomas, Hannah Fischer, Julissa Gomez-Granger, and Anne Leland, 2009. "China's Foreign Aid Activities in Africa, Latin America, and Southeast Asia.” Washington, D.C.: Congressional Research Service.

Mancheri, Nabeel A. 2012 "China’s Chequebook Diplomacy in Africa", in Foreign Policy Journal, August 17, http://www.foreignpolicyjournal.com/2012/08/17/chinas-chequebookdiplomacy-in-africa/ accessed November 20, 2013.

Organski, A.F.K. and Jacek Kugler, The War Ledger. Chicago: University of Chicago Press, 1981.

Raluca Besliu, 2013. "Will China Win the Battle Over Africa?” by in Foreign Policy Journal July 13. Online http://www.foreignpolicyjournal.com/2013/07/13/will-china-win-the-battleover-africa/ accessed November 20, 2013.

Santibañes, Francisco, "An End to US Hegemony? The Strategic Implications of China’s Growing Presence in Latin America," Comparative Strategy, 28 (1), (2009), pp.17-36.

Spanakos, Anthony P. "China and the Rise of the BRICS," Gungwu Wang and Yongnian Zheng Ed., China: Development and Governance, Singapore: World Scientific, 2012.

and Joseph Marques, "The Chinese Contribution to Brazil's Rise as Middle Power," Bruce Gilley and Andrew O'Neil Ed., Middle Powers and the Rise of China, Washington, D.C.: Georgetown University Press, forthcoming.

Qin Yaqing's "Why is there no Chinese international relations theory?" (2005) http://www. irchina.org/en/xueren/china/qyq.asp accessed on 28 May 2011.

Tullo Vigevani and Gabriel Cepaluni, 2009. Brazilian Foreign Policy in Changing Times: The Quest for Autonomy from Sarney to Lula. Lanham: Lexington Books. Translated by Leandro Moura.

Woods, Ngaire. 2008. "Whose aid? Whose influence? China, emerging donors and the silent revolution in development assistance” in International Affairs 84:6, 1205-1221, page 1205.

Zhiqun Zhu, "Power Transition and US-China Relations: Is War Inevitable?" Journal of International and Area Studies, 12, no. 1 (2005) 1-2. 


\section{Abstract}

The rise of large developing countries has led to considerable discussions of re-balancing global relations and giving greater priority to understanding South-South relations. This paper, in exploring the central ideas of Chinese and Brazilian foreign policy and the behavior of these two rising Southern countries toward Sub-Saharan Africa, argues that the English School of International Relations is well suited to understanding the intentions and actions that characterize South-South relations.

Keywords: Brazil; China; English School.

\section{Resumo}

O grande aumento de países em desenvolvimento tem levado à ocorrência de discussões consideráveis acerca de um reequilíbrio nas relações globais e dado maior importância à compreensão das relações Sul-Sul. Este trabalho explora as ideias centrais da política externa chinesa e brasileira e o comportamento destes dois crescentes países do Sul em direção à África Subsaariana, argumentando que a Escola Inglesa de Relações Internacionais é a mais adequada para a compreensão das intenções e ações que caracterizam as relações Sul-Sul.

Palavras-chave: Brasil; China; Escola Inglesa. 